\title{
PENGARUH KOMUNIKASI VERBAL TERHADAP PERKEMBANGAN BAHASA ANAK
}

\author{
Nia Rusmiati ${ }^{1}$, Mira Mayasarokh ${ }^{2}$ \\ KB Al-Furqon Salareuma ${ }^{1}$ \\ Prodi Pendidikan Anak Usia Dini, STKIP Muhammadiyah Kuningan ${ }^{2}$ \\ Email : niarusmiati628@gmail.com ${ }^{1}$, mira@upmk.ac.id ${ }^{2}$
}

\begin{abstract}
Abstrak
Tujuan dari penelitian ini adalah untuk mengetahui perkembangan komunikasi verbal anak di Kelompok Bermain Al-Furqon desa Salareuma, untuk mengetahui perkembangan bahasa anak di Kelompok Bermain Al-Furqon desa Salareuma, untuk mengetahui pengaruh komunikasi verbal terhadap perkembangan bahasa anak di Kelompok Bermain Al-Furqon desa Salareuma. Metode penelitian yang di gunakan dalam penelitian ini adalah metode deskriftip kuantitatif.Dari hasil penelitian diperoleh kesimpulan bahwa komunikasi verbal dalam kriteria berkembang sangat baik sebesar $60 \%$. Perkembangan bahasa dalam kriteria berkembang sesuai harapan sebesar $46,7 \%$. Terdapat pengaruh positif antara komunikasi verbal terhadap perkembangan bahasa anak sebesar 58,6\%.
\end{abstract}

Kata kunci : Komunikasi Verbal, Perkembangan Bahasa Anak.

\begin{abstract}
The objectives of this study were to determine the development of verbal communication of children in the Al-Furqon Playgroup of Salareuma village, to find out the language development of children in the Al-Furqon Playgroup of the village of Salareuma. to determine the effect of verbal communication on children's language development in the Al-Furqon Playgroup of Salareuma village. The research method used in the research is the quantitative descriptive method.From the results of the study concluded that verbal communication in criteria developed very well by $60 \%$. Language development in criteria developed according to expectations of $46.7 \%$. There is a positive influence between verbal communication on children's language development by $58.6 \%$.
\end{abstract}

Keywords: Verbal Communication, Child Language Development.

(c) 2019 Nia Rusmiati ${ }^{1}$, Mira Mayasarokh ${ }^{2}$ Under the license CC BY-SA 4.0

http://jurnal.upmk.ac.id/index.php/pelitapaud 
PENDAHULUAN

Pendidikan Anak Usia Dini (PAUD) merupakan suatu upaya pembinaan yang ditujukan kepada anak sejak lahir sampai dengan usia 6 (enam) tahun yang dilakukan melalui pemberian rangsangan pendidikan untuk membantu pertumbuhan dan perkembangan jasmani dan rohani agar anak memiliki kesiapan dalam memasuki pendidikan lebih lanjut (Permendikbud, 2014:3).

Komunikasi antar anak dapat terjalin secara baik dengan bahasa, sehingga anak dapat membangun hubungan sehingga tidak mengherankan bahwa bahasa dianggap sebagai salah satu indikator kesuksesan seorang anak. Anak yang dianggap banyak berbicara, kadang merupakan cerminan anak yang cerdas.Bahasa merupakan struktur dan makna yang bebas dari penggunanya, sebagai tanda yang menyimpulkan suatu tujuan.Adapun menurut kamus besar bahasa Indonesia bahasa berarti sistem lambang bunyi yang arbitrer, digunakan oleh semua orang atau anggota masyarakat untuk bekerjasama, berinteraksi, dan mengidentifikasi diri dalam bentuk percakapan yang baik, tingkah laku yang baik, sopan santun yang baik. Perkembangan bahasa verbal pada anak usia dini merupakan suatu dasar terbentuknya komunikasi. Berbagai penelitian menunjukan bahwa pembentukan keterampilan berbicara sangat penting baik pada anak usia dini maupun pada saat anak mulai masuk pendidikan dasar. Keterampilan berbicara merupakan kemampuan yang sangat mendasar dan penting dalam menjalin hubungan sosial.Anak-anak harus didorong untuk berbicara dengan baik.

Keterampilan berbicara menjadi kebutuhan agar anak dapat menjadi bagian dari kelompok sosialnya sekaligus menjadikan keseimbangan berbagai perkembangan. Pada masa anak merupakan waktu yang sangat penting dalam pembelajaran berbicara. Sebab dengan berbicara anak akan aktif mencari makna dan akan mencari jalan untuk berkomunikasi dengan anak. Bahasa pada umumnya masih menggunakan struktur bahasa yang masih kacau dan masih mengalami tahap transisi dalam berbicara, sehingga sukar untuk dipahami oleh mitra tuturnya.Selain menggunakan struktur bahasa yang masih kacau, anak-anak juga cenderung masih memiliki keterbatasan dalam kosa kata dan dalam pelafalan fonemnya secara tepat.Lingkungan sangat mempengaruhi perkembangan bahasa anak.Seorang 
mitra tutur pada anak harus menguasai kondisi atau lingkungan sekitarnya untuk dapat memahami maksud dari pembicaraan anak.

Lingkungan keluarga merupakan tempat pertama kali anak belajar dan mengenal tentang nilai-nilai kehidupan.Pada saat anak pertama kali lahir di dunia, anaksudah mulai belajar dan mengenal tentang lingkungannya. Orangtua merupakan tokoh utama dalam pembentukan pribadi, model yang dijadikan contoh anak dalam berperilaku serta sosok yang berpengaruh dalam perkembangan anak.Sedangkan lingkungan masyarakat merupakan tempat anak belajar bersosialisasi dan mengenal tentang norma-norma sosial.

Lingkungan masyarakat juga berpengaruh terhadap perkembangan anak.Komunikasi mempunyai dua sifat umum, yaitu langsung dan tidak langsung. Komunikasi langsung berupa proses tatap muka (face to face) antara manusia satu dengan manusia lain. Berbeda dengan komunikasi langsung, dalam komunikasi tidak langsung manusia memerlukanperantara atau media untuk menghubungkan manusia satu dengan manusia lain, misalnya: $\mathrm{TV}$, internet, surat kabar, dan lain-lain.

Dalam peneltian ini masih terdapat anak yang susah untuk berkomunikasi dengan temannya. Oleh karena itu peneliti masih ingin mengetahui metode metode apa saja yang yang seharusnya dilakukan agar komunikasi verbal anak bisa berkembang sesuai perkembangan anak, pada kesimpulannya bahwa komunikasi adalah inti dari semua hubungan dengan tingkat kedalam yang bervariasi. Perkembangan bahasa tersebut sangat penting dilakukan pada anakusia dini, karena dapat memberikan stimulus pada anak agar tidak terdapat hambatan dalam proses belajar. Ketika anak memiliki kemampuan komunikasi yang rendah dapat mengakibatkan berbagai hambatan dalam proses berbicara, seperti anak sulit berkomunikasi dengan teman.

Perkembangan bahasa sangat penting peranannya dalam masa tumbuh kembang seoranganak.Karena perkembangan bahasa menunjang perkembangan lainnya di diri seorang anak.Oleh karena itu apabila perkembangan bahasa seorang anak tidak berkembang, selayaknya sebagai orang tua atau pendidik perlu adanya tanggap untuk segera mencari penyelesaian penyebab mengapa anak tersebut mengalami masalah dalam perkembangan bahasanya (Zulela et al, 2017 : 23).Bahasa tidak bisa dipisahkan dari kehidupan manusia, sehingga dapat dikatakan bahwa bahasa adalah milik 
manusia yang telah menyatu dengan pemiliknya.Karena bahasa adalah alat untuk menyampaikan isi pikiran, perasaan, alat untuk menyampaikan ekspresi dan interaksi dengan orangorang dan lingkungan di sekitar kita.

Berdasarkan hasil observasi yang di lakukan di Kelompok Bermain AlFurqon Desa Salareuma tedapat anak yang belum lancar dalam berbicara selain itu juga masih terdapat anak yang belum mampu membaca, mengenal dan menyebutkan huruf, hal ini dipengaruhi oleh faktor orang tua yang terlalu sibuk dengan kegiatannya masingmasing.faktor orang tua juga yang mempengaruhi pemerolehan bahasa anak, karna anak dibatasi untuk bergaul dan bersosialisasi dengan lingkungan sekitar, sehingga anak kurang mendapatkan banyak informasi.Faktor guru dalam menggunakan metode dan strategi pemebelajarannya belum mampu meningkatkan perkembangan bahasa verbal anak sehingga masih terdapat anak yang belum berkembang bahasa verbalnya.

\section{METODE PENELITIAN}

\section{Jenis Penelitian}

Penelitian ini mengunakan pendekatan deskriptip kuantitatif.

Waktu dan tempat penelitian
Penelitian ini dilakukan pada bulan Mei 2019. Bertempat di KB Al-Furqon desa salareuma kecamatan cipicung.

\section{Subyek Penelitian}

Populasi yang digunakan dalam penelitian ini menurut Sugiyono (2008:115) adalah wilayah generalisasi terdiri atas obyek/subyek yang mempunyai kualitas dan karakteristik tertentu. ditetapkan oleh peneliti untuk dipelajari dan kemudian ditarik kesimpulan". Dalam penelitian ini populasinya adalah siswa kelompok B kelompok bermain Al-Furqon yang berjumlah 30 siswa.

Sampel yang di gunakan dalam penelitian ini menurut Sugiyono (2008:116) adalah sebagian dari jumlah dan karakteristik yang dimiliki oleh populasi tersebut. dan menurut Hasan (2002 : 58) bahwa sampel adalah bagian dari populasi yang diambil melalui cara cara tertentu yang juga memiliki karakteristik tertentu, jelas dan lengkap yang dianggap bisa mewakili populasi. Penarikan sampel dilakukan dengan cara memilih anak berdasarkan ciri-ciri atau karakteristikanak yang akan diteliti. Dengan ketentuan : 1. Anak belum mampu menyebutkan huruf. 2.anak mengalami keterlambatan dalam berbicara. 3. Anak belum bisa 
bersosialisasi dengan temannya dll. maka sampel yang digunakan dalam penelitian ini adalah 15 anak yang diambil dari jumlah populasi yaitu 30 anak.

Instrumen penelitian yang digunakan dalam penelitian ini adalah lembar observasi. Menurut Margono (2007: 159), observasi digunakan untuk melihat dan mengamati perubahan fenomena-fenomena sosial yang tumbuh dan berkembang yang kemudian dapat dilakukan perubahan atas penilaian tersebut, bagi pelaksana observaser untuk melihat obyek moment tertentu, sehngga mampu memisahkan antara yang diperlukan dengan yang tidak diperlukan.Lembar

Teknik yang digunakan untuk mengumpulkan data dalam penelitian ini adalah observasi. Adapun kegiatan yang diamati yaitu, melihat kemampuan menyimak (listening) juga kemampuan dalam berbicara (speaking) serta melihat penambahan kosa kata yag dimilikinya dan lain-lain. Alat yang digunakan untuk mengumpulkan data penelitian ini adalah observasi selama proses kegiatan pembelajaran berlangsung.

Dokumentasi digunakan sebagai data pendukung untuk memberikan gambaran mengenai partisipasi anak pada saat proses pembelajaran serta observasi ini berisi pernyataan mengenai perilaku siswa selama pelaksanaan pembelajaran. Kemampuan komunikasi verbal yang dimaksud dalam penelitian ini adalah kemampuan siswa dalam aspek kebahasaan dan non kebahasaan (Nurbiana, 2008: 36). Aspek kebahasaan yaitu ketepatan pengucapan, penempatan tekanan, nada, dan durasi yang sesuai, pilihan kata (diksi), dan ketepatan sasaran pembicaraan. Sedangkan aspek non kebahasaan yaitu sikap yang wajar, tenang, dan tidak kaku, pandangan harus diarahkan kepada lawan bicara, gerak gerik dan mimik yang tepat, kenyaringan suara, kelancaran, dan penguasaan topik pembicaraan.

untuk memperkuatkan data yang telah diperoleh. Dokumen tersebut berupa foto anak yang selama mengikuti proses pembelajaran. Foto tersebut berfungsi sebagai gambar nyata kegiatan penting di dalam kelas dan menggambarkan partisipasi anak ketika proses pembelajaran tersebut berlangsung.

Teknik analisis data menggunakan metode chi-kuadrat/chi-square. Metode ini digunakan untuk mengadakan pendekatan dari beberapa faktor atau mengevaluasi frekuensi yang diselidiki atau frekuensi hasil observasi (fo) dengan frekuensi yang diharapkan (fe) dari sampel apakah terdapat hubungan 
atau perbedaan yang signifikan atau tidak.

Untuk mengukur keberhasilan perkembangan bahasa dalam meningkatkan komunikasi verbalanak dilihat dari persentase yang sama untuk menentukan berhasil atau tidaknya tindakan yaitu pada presentase dengan keterangan sangat baik.Dalam penelitian ini, untuk mengetahui ada tidaknya korelasi antara komunikasi verbaldengan perkembangan bahasa anak, maka pengolahan data penelitian ini menggunakan rumus analisis Korelasi Product Moment.

Variabel yang diujikan adalah korelasi antar dua variabel yang terdiri dari dependent varibel yaitu varibel yang terikat atau variabel yang dipengaruhi dan independent variabel atau disebut juga variabel bebas. Karena penelitian ini membahas dua variabel yang diteliti untuk selanjutnya dilakukan tabulasi data, diolah dengan rumus statistik dan dilakukan analisis. Adapun teknik analisis data yang dilakukan yaitu menggunakan SPSS.
Analisis data adalah proses penyederhanan data kedalam bentuk yang mudah di baca dan di interprestasikan, dalam proses ini digunakan statistik yang salah satu fungsinya adalah untuk menyederhanakan data penelitian yang besar jumlahnya menjadi informasi yang lebih sederhana dan sudah di pahami. Teknik analisis data yang digunakan sesuai dengan tujuan yang hendak di capai. Berdasarkan jenis data yang di kumpulkan yaitu data kuantitatif,maka teknik yang digunakan adalah analisis statistik sebagai berikut:

Berdasarkan perhitungan statistik variabel komunikasi verbal diketahui bahwa jumlah sekor komunikasi verbal adalah sebesar 1251, banyaknya item observasi komunikasi verbal sebanyak 14 item sampel sebanyak 15 anak, dengan mean 83,39\%, standart eror 765. Median (nilai tengah) 82,90. Mode atau modus sebesar 83, dengan standar deviation 2,963, variance 8,781 , nilai range 10 , nilai minimum 80 , dan nilai maksium 9.

Tabel 1. Frekuensi Perkembangan Bahasa

\begin{tabular}{lcll}
\hline Skor & $\begin{array}{c}\text { Kriteria } \\
\text { penilaian }\end{array}$ & F & $\%$ \\
\hline 100 & BSB & 9 & 60 \\
80 & BSH & 4 & 26.6 \\
\hline
\end{tabular}




\begin{tabular}{llll}
\hline 60 & MB & 2 & 13,4 \\
$0-40$ & BB & 0 & \\
Total & & 15 & 100 \\
\hline
\end{tabular}

Dapat diketahui bahwa dari 15

sampel anak, sebanyak 9 anak atau 60\% anak memiliki komunikasi verbal dengan kriteria berkembang sangat baik, artinya bahwa pada dasarnya anak sudah mampu berkomunikasi dengan lingkungan sekitarnya. Tapi ada beberapa item yang di hasilkan dari lembar komunikasi verbal yang harus di tingkatkan.
Berdasarkan perhitungan statistik variabel perkembangan bahasa diketahui bahwa jumlah sekor perkembangan bahasa adalah sebesar 1296, banyaknya item observasi komunikasi verbal sebanyak 4 item sampel sebanyak 15 anak, dengan mean $86,43 \%$, mode 83, dengan standar deviation 3,589, variance 12,878 , nilai range 11 , nilai minimum 81, dan nilai maksium 93.

Tabel 3. Frekuensi Perkembangan Bahasa

\begin{tabular}{cclc}
\hline Skor & $\begin{array}{c}\text { Kriteriua } \\
\text { penilaian }\end{array}$ & F & $\%$ \\
\hline 100 & BSH & 8 & 46.7 \\
80 & BSB & 7 & 33,3 \\
60 & MB & 0 & \\
$0-40$ & BB & 0 & 100 \\
Total & & 15 & \\
\hline
\end{tabular}

Dari tabel diatas dapat diketahui bahwa dari 15 sampel anak sebanyak 8 anak atau $46,7 \%$ perkembangan bahasa anak dengan kriteria penilaian berkembang sesuai harapan dengan kriteria berkembang sangat baik sebanyak $33,3 \%$, artinya bahwa pada dasarnya perkembangan bahasa anak sudah baik.

Uji korelasi poduk moment dilakukan untuk mengetahui vaiabel satu dengan yang lainya.Maksud variabel dalam penelitian ini adalah pengaruh komunikasi verbal terhadap perkembangan bahasa anak. Untuk membuktikan hal tersebut dihitung dengan menggunakan rumus SPSS“ produk moment"

Pada perhitunganuji korelasi protuk moment terjadi sel korelasi komunikasi verbal terhadap perkembangan bahasa anak dalam sel tersebut terdapat 3 angka, yaitu: Angka 0,765 menunjukan koefisien korelasi produk moment dengan tanda bintang dua (**) tanda tersebut menunjukan koefisien korelasi signifikasi pada tingkat signifikasi 0,001.Angka 0,001 menunjukan tingkat 
signifikansi.Karna tingkat signifikasi

(1- ujung) koefisien korelasi tersebut dibawah 0,005 dengan arah positif maka korelasi antara komunikasi verbal dengan perkembangan bahasa dinyatakan signifikan positif.Angka 15 menunjukn ukuran sampel atau jumlah pengamatan pada kasus ini.

Pada hasil uji normalitas diketahui bahwa nilai sign untuk komunikasi verbal adalah $220>0,005$ dan nilai sign untuk perkembangan bahasa 0,609> 0,005. Maka dapat disimpulkan data untuk komunikasi verbal dan perkembangan bahasa anak berdistribusi normal, karna nilai sign dari dua data tersebut lebih besar dari 0,005 maka berdistri busi normal, dan jika nilai sign nya lebih kecil dari 0,005 artinya berdistribusi tidak normal.

Pengujian Hipotesis dengan uji t. Diketahui bahwa nilai sign untuk pengaruh komunikasi verbal terhadap perkembangan bahasa anak adalah sebesar $0,001<0,05$ dan nilai t hitung 4,289 > dari t tabel 2,160, sehingga dapat disimpulkan bahwa Ha di terima yang berarti terdapat pengaruh komunikasi verbal terhadap perkembangan bahasa anak.

Pengujian Hipotesis dengan uji fdiketahui nilai signifikansi untuk pengaruh komunikasi verbal terhadap perkembangan bahasa adalah $0.001<$ 0,05 dan nilai $\mathrm{F}$ hitung 18,393> 4,60, sehingga dapat disimpulkan bahwa $\mathrm{Ha}$ diterima yang berarti terdapat pengaruh komunikasi verbal terhadap perkembangan bahasa anak.Berdasarkan koefisien determinasi diketahui bahwa nilai R Square sebesar 0,586, hal ini mengandung arti bahwa pengaruh komunikasi verbal (x) terhadap perkembangan bahasa anak (y) sebesar 58,6\%.

\section{HASIL PENELITIAN DAN PEMBAHASAN}

Penelitian ini dilakukan mulai bulan Mei 2019, pertemuan pertama dilakukan untuk melihat atau mengobservasi kegiatan pembelajaran anak selama disekolah dengan melakukan dokumentasi dan melakukan analisis data perkembangan komunikasi verbal dan perkembangan bahasa dengan menggunakan lembar observasi.

Penelitian ini bertujuan untuk mengetahui pengaruh komunikasi verbal terhadap perkembangan bahasa anak di KB AL-FURQON Desa Salareuma.Dari hasil analisis korelasional data menunjukan bahwa terdapat hubungan positif yang signifikan antara komunikasi verbal dan perkembangan bahasa anak. Hal ini di 
buktikan dengan hasil perhitungan uji hipotesis yang telah di lakukan dengan pengolahan data menggunakan SPSS dengan melihat nilai koefisien bertanda positif berarti terjadi hubungan yang positif artinya jika pengaruh komunikasi verbalnya tinggi maka perkembangan bahasa anak akan meningkat atau berkembang.

Untuk mengetahui ada atau tidaknya pengaruh komunikasi verbal terhadap perkembngan bahasa anak maka peneliti menggunakan instrumen berupa lembar observasi. Sebelum melakukan penelitian peneliti melakukan uji instrumen terlebih dahulu selama proses pembelajaran berlangsung di KB AL-FU-RQON Desa Salareuma.

Berdasarkan hasil penelitian peneliti melakukan observasi dengan menggunakan lembar observasi. untuk melakukan penilaian komunikasi verbal terhadap perkembangan bahasa anak dengan lembar observasi dimana terdapat 4 kriteria penilaian seperti : kolom Belum Berkembang (BB) Skor 0-40. Mulai Berkembang (MB) Skor 60, Berkembang Sesuai Harapan (BSH) Skor 80. Berkembang Sangan Baik (BSB) 100 .

Hasil uji normalitas diketahui bahwa nilai sign untuk komunikasi verbal adalah $220>0,005$ dan nilai sign untuk perkembangan bahasa 0,609 > 0,005. Maka dapat disimpulkan data untuk komunikasi verbal dan perkembangan bahasa anak berdistribusi normal, karena nilai sign dari dua data tersebut lebih besar dari 0,005 maka berdistribusi normal, dan jika nilai sign nya lebih kecil dari 0,005 artinya berdistribusi tidak normal.

Nilai rata rata variabel komunikasi verbal yaitu $83.39 \%$, dan nilai rata rata variabel perkembangan bahasa 86.43 $\%$.Hasil uji Hipotesis untuk variabel komunikasi verbal terhadap perkembangan bahasa dengan nilai yang di peroleh yaitu hitung 4,289> dari t tabel 2,160, Dan nilai $\mathrm{F}$ hitung $4.289>4,60, \quad$ sehingga dapat disimpulkan bahwa Ha di terima yang berarti terdapat pengaruh komunikasi verbal terhadap perkembangan bahasa anak di kelompok B KB AL-FURQON Desa Salareuma.

\section{SIMPULAN}

Berdasarkan hasil analisis data diatas yang di peroleh dari hasil observasi pengaruh komunikasi verbal terhadap perkembangan bahasa anak kelompok $\mathrm{B} \mathrm{Kb} \mathrm{Al}$ Furqon Desa Salareuma.

Perkembangan Komunikasi verbal anak kelompok B $\mathrm{Kb}$ Al-Furqon Desa salareuma dapat diketahui bahwa dari 
15 sampel anak, sebanyak 9 anak atau $60 \%$ anak memiliki komunikasi verbal dengan kriteria berkembang sangat baik, artinya bahwa pada dasarnya anak sudah mampu berkomunikasi dengan lingkungan sekitarnya.

Perkembangan bahasa kelompok B $\mathrm{Kb}$ Al-Furqon desa Salareuma dapat diketahui bahwa dari 15 sampel anak, sebanyak 8 anak atau $46,7 \%$ perkembangan bahasa anak dengan kriteria penilaian berkembang sesuai harapan dan kriteria berkembang sangat baik sebanyak 33,3\%, artinya bahwa pada dasarnya perkembangan bahasa anak sudah baik.

Pengaruh Komunikasi verbal terhadap perkembangan bahasa anak Kelompok B $\mathrm{Kb}$ Al-Furqon desa Salareuma sebesar 58,6\%. Artinya ada $41,4 \%$ faktor lain yang mempengaruhi perkembangan bahasa.

\section{DAFTAR PUSTAKA}

Sugiono. (2011). Metode Penelitian Pendidikan. Bandung: Alfabeta.

Nurbiana, dkk. (2008). Metode Pengembangan Bahasa. Jakarta: Pusat Penerbitan Universitas Terbuka.

Dewi, puspa, maya, kadek. Dkk. (2018). Pengaruh sosidrama terhadap kemampuan komunikasi verbal anak paud dharma wangsa denpasar barat,
Jurnal Pendidikan Anak Usia Dini, Vol 6, No. 1.

Jannah, Nur, Ita. (2017) Skripsi, Peningkatan Kemampuan Komunikasi LisanMelalui Teknik Sosiodrama.

Kristiono. Natal, Mutmainah, (2018). "Pemanfaatan Media Wayang Kertas untuk Meningkatkan Mutu Perkembangan Karakter Bahasa Anak Dalam Berkomunikasi”. Jurnal Penjaminan Mutu, Vol 4 No 2.

Mahmud, Teuku. (2018). Peningkatan Kemampuan Berkomunikasi Lisan Melalui Metode Bermain Peran Pada Anak Kelompok B Di Tanam kanakkanak Aisyiyah Merduati Banda Aceh. Jurnal Metamorfosa, Volume 6, No. 2.

Nurhasanah, (2017) Skripsi, Upaya Meningkatkan Kemampuan Berkomunikasi Lisan Melalui Metode Bercerita Di Ra AlIhsanBanten No.02 Laut Dendang. 